\title{
Program of Sarjana Mengajar to Improve the Quality of Education on Vocational High School
}

\author{
Riana Nurmalasari, Eddy Sutadji, Djoko Kustono \\ State University of Malang \\ Malang, Indonesia \\ riananurmalasari28@gmail.com
}

\begin{abstract}
The shortage of teachers and the distribution of teachers was still a problem in the education system in Indonesia. In response to the problem, one of the government's effort was by rolling sarjana mengajar program. The goals of this research are to describe more deeply about the role of sarjana mengajar program to improve the quality of education in terms of success in the fulfilment of vocational high school teachers, learning management, and improving the quality of learning. This research was a qualitative descriptive study with multi-site research. In this study, the researcher were a key instrument of primary data collectors. The data collection phase consisted of interviews, observation, and documentation. The techniques of data analysis were descriptive qualitative analysis. Checking the validity of the data through perseverance observation, repeated observations, and triangulation of data. Based on the data analysis results, there were three conclusions. First, sarjana mengajar program was on target for the fulfillment of vocational high school teachers in the school target. Second, the role of sarjana mengajar participants for developing learning management in school target was already quite good, but still, need improvement in some aspects of that learning objectives can actually be achieved. Third, sarjana mengajar program had a role in improving the quality of learning in schools target but still needed more in-depth scrutiny to continue improving the quality of learning.
\end{abstract}

Keywords - sarjana mengajar, teacher, vocational high school

\section{INTRODUCTION}

The government keep on to develop secondary education, especially vocational education in various parts of Indonesia. Statistics of the Ministry of Education and Culture shows the number of vocational high school in Indonesia has increased $17 \%$ since 2012 to 2015 . The increase in the number of vocational high school is should be followed by the increase in the number of teachers. Unfortunately, according to the statement from the Director of the Directorate of Technical and Vocational Education, Drs. Mustaghfirin M. Amin, M.B.A stated that every year Indonesia is still short of productive teachers, every year there are only 4000 teachers from all LPTKs in Indonesia [1]. This is in line with Sunandar's opinion [2] which states that the shortage of teachers and even distribution of teachers remains one of the problems in the education system in Indonesia.

In response to the problem, since 2008 the Directorate General of Teachers and Education Personnel, Directorate
General of Elementary and Secondary Education has rolled Vocational Education Implementation Assistance Program or now called sarjana mengajar. Sarjana mengajar is a program conducted by the Higher Education Institutions that have experience and competence to provide guidance and services for development vocational high school, improving the quality of learning, development of innovation and learning tools, build learning resources, help extracurricular activities and school administrative arrangement [3]. The goals of this research are to describe more deeply about the role of sarjana mengajar program to improve the quality of education in terms of success in the fulfilment of vocational high school teachers, learning management, and improving the quality of learning.

\section{METHOD}

This research is a qualitative descriptive study with multisite research. The subject of this study consists of 4 headmasters, 10 teachers productive machining techniques, 5 participants of sarjana mengajar program, and 20 students from each school of interest SMKN 4 Bojonegoro, SMKN 1 Tuban, SMKN 3 Tuban, and SMKN 3 Boyolangu Tulungagung. In this study, the researcher are a key instrument of primary data collectors. The data collection phase consisted of interviews, observation, and documentation. The techniques of data analysis are descriptive qualitative analysis. Checking the validity of the data through perseverance observation, repeated observations, and triangulation of data.

\section{RESULT AND DISCUSSION}

\section{A. Sarjana Mengajar Program for Fulfillment Productive} Teachers of Vocational High School

One of the things behind sarjana mengajar program is the reality on the ground suggest that many new schools unit has not been productive enough teachers if any, these teachers do not have the appropriate educational background [4]. This program is deemed relevant to the purpose the Ministry of Education and Culture which one of them is to realize an increase in the quality, relevance, and competitiveness. Interest is expected to be achieved through the development and improvement of the quality of the vocational high school. This is because various research and analysis show that science and 
technology and the quality of human resources (HR) is a key factor in determining the competitiveness of a nation [5]. Furthermore, research conducted by Widarto [6] showed that there are positive role vocational high school in technology group for the growth of manufacturing industries nationwide.

Based on the research results obtained, it is known that the sarjana mengajar program enough to help schools target for fulfilment productive teachers. It is based on information obtained from the study subjects who stated that the school was helped by the sarjana mengajar program. Lack of teachers in school target of sarjana mengajar program led to the burden of teaching the teacher becomes abnormal or exceed it should be. Consequently, the learning process cannot be run optimally. After implementation of sarjana mengajar program, teaching loads of teachers become normal and learning can be implemented better.

The teacher is one important aspect in ensuring the ongoing quality learning [7]. According to the Education Management Team Malang [8], ideal ratio between teachers and students is a teacher versus 24 to 26 students. The ideal size is a guarantee for the service provided by the teacher to the student. Service teachers to students is a form of teachers' role in ensuring the quality of teaching quality in the classroom [9]. This is in line with the opinion of Wang and Fwu [10] which states that impossible to create a good education without quality teachers are able to perform learning effectively to achieve educational goals.

Studies conducted Heynemen \& Loxley in 1983 in 29 countries found that among the various inputs (input) that determine education (indicated by learning outcomes) was determined by the one-third of teachers [11]. Sanjaya [12] suggests that the main role of a teacher is to present science as a cultural heritage of the past were considered useful and should be preserved. This is supported by the opinion of Toth [13] which states that effective learning can only happen if the teacher determines the method, form, and meaning of learning that will be delivered to students by taking into account the characteristics of the students. Furthermore, Bandura [14] found that effective learning can affect the acceptance of theoretical knowledge to students. Teachers act as facilitators and mediators that allow the creation of conditions conducive for students to learn and be responsible for the achievement of learning outcomes [15] [16]. Teachers have a very important role in the learning process, although it has been developed distance learning with technology [17], however, the teacher's role is still needed. Given the role that is so important, then teachers are required to have an understanding and ability to comprehensively about his competence as an educator. Teachers need to be nurtured continuously in order to improve the quality of education [18].

Based on some opinions stating that the presence of a teacher is quite important to the learning process and based on data obtained during the research it can be said that the sarjana mengajar program was on target for the fulfilment of vocational high school teachers in the school target.

\section{B. Sarjana Mengajar Program for Development Learning Management}

The work program of sarjana mengajar consists of learning programs and non-learning program [19]. Learning program consists of tools used as lesson preparation, carrying out teaching practices, and creating learning media. Observations indicate that the participants of sarjana mengajar have a learning device, the participants carry out teaching activities independently, as well as the participants using instructional media for delivery of material. Further interviews and documentation showing that the participants create a learning tool at the beginning of the semester in accordance with the curriculum and the spectrum vocational high school to be used as a reference for learning which will be implemented for a semester, the participants carry out teaching activities independently with the provision of knowledge and experience gained in the lecture bench and the participants make learning media for delivery of material in the classroom with the intention that the students interested and more enthusiastic about learning.

Furthermore, the information obtained from the study subjects stated that the role of the participant as a teacher of sarjana mengajar contribute for learning management in school target. Explained that learning management is getting better with their learning device, learning not only using the conventional system, evaluation of authentic assessment, teaching methods appropriate to the material being taught, as well as the use of instructional media interest. Learning management is closely related to the role of a teacher as class manager. Low teacher skills in classroom management will not be able to complete a lot of things that their main duty [20].

Participants of sarjana mengajar make learning device in accordance with the competencies that will be studied. In this case, the learning device is one of the important things for the achievement of learning objectives. This is in line with stated by Sumarno [21]; [22] which states that teachers should develop learning tools carefully studies according to the learning outcomes. A learning plan will facilitate the achievement of set targets prior to implementation is done, determine the steps that must be executed during the execution, as well as facilitate the evaluation after the implementation process [23].

During the implementation of learning, teaching undergraduate participants not only taught conventionally. Participants undergraduate teaching using several methods of learning appropriate to resolve a particular matter. In addition, during the implementation of learning characteristics of learners were also considered. This is because if less learning implementation in accordance with the characteristics of students can lead to patterns of interactions that occur in the process of learning becomes less active and less attractive for students [24]. Related evaluation of learning, it is known that the participants of sarjana mengajar program tried to assess students with authentic assessment. Authentic assessment is performed to measure the learning process and student learning outcomes as a whole [25]. Based on research data that has been described above it can be concluded that the participants of sarjana mengajar are already implementing work programs as it 
should. The role of sarjana mengajar participants for developing learning management in school target was already quite good, but still, need improvement in some aspects of that learning objectives can actually be achieved.

\section{Sarjana Mengajar Program for Improved Quality of Learning}

The quality of teaching is a student's ability to manage operationally and efficiently to the components related to learning resulting in added value to the components based on standards [26]. The results of research related to improving the quality of learning in sarjana mengajar program showed that there is an increase in the quality of learning. This is evidenced by the increase in the value of students, participation of students in competitions between schools up to the national scale, the achievement of the effectiveness of learning is by delivering all material according to competency standards and basic competencies, the realization of additional classes in one school target, improve student activity during learning, and increasing the value of discipline students for learning. Some of it shows that there is a change in a more positive direction related to the quality of learning.

Previous research related to sarjana mengajar program conducted by Nurmalasari [27] also showed indications of a change in a positive direction after the arrival of the participants of sarjana mengajar in schools target. It can be seen from the relationship between implementation of sarjana mengajar program and students perception during learning. Observations prior to the sarjana mengajar program showed that student interest is low and passive evidenced by students' grades were mostly less than score standards. While the conditions that occurred after implementation of sarjana mengajar program showed some changes like the student's courage to compete, student scores increased, students are more active during learning, and the relationship between teachers and students become closer emotionally.

Based on the results obtained during the study, it can be said that in general sarjana mengajar program had a role in improving the quality of learning in schools target, but still needed more in-depth scrutiny to continue improving the quality of learning. Given closely related to the quality of supervision in a professional manner [28].

\section{CONCLUSION}

Based on the results of research and discussion in the previous chapter, it can be concluded as follows. First, sarjana mengajar program was on target for the fulfilment of vocational high school teachers in the school target. Second, the role of sarjana mengajar participants for developing learning management in school target was already quite good, but still, need improvement in some aspects of that learning objectives can actually be achieved. Third, sarjana mengajar program had a role in improving the quality of learning in schools target but still needed more in-depth scrutiny to continue improving the quality of learning.

\section{ACKNOWLEDGMENT}

We gratefully thanks to all subject who contribute on this research.

\section{REFERENCES}

[1] Anonim. (2014). Guru Produktif SMK, (Online), (http://www.republika.co.id/berita/pendidikan/eduaction/14/10/27/ne 3cnf-dicari-7000-guru-produktif-smk-tiap-tahun), diakses 28 November 2016.

[2] Sunandar. (2006). Analisis Perencanaan Kebutuhan Guru. Jurnal Manajemen Pendidikan. 1(2): 1-13.

[3] Anonim. (2013). Panduan Workshop Pembekalan Pemenuhan Guru Produktif SMK. Jakarta: Kementerian Pendidikan dan Kebudayaan.

[4] Iskandar, Fuad. (2012). Evaluasi Pelaksanaan Program Pendampingan Penyelenggaraan Pendidikan Kejuruan Direktorat Pembinaan SMK. Tesis tidak diterbitkan. Jakarta: FISIP UI.

[5] Wen. (2003). Future of Education. Batam: Lucky Publishers.

[6] Widarto. (2007). Peranan SMK Kelompok Teknologi terhadap Pertumbuhan Manufaktur. Jakarta: Direktorat Pembinaan SMK Depdiknas.

[7] Sujati, H. (2015). Analisis Kebijakan Penataan Guru PNS. Prosiding Universitas PGRI Semarang 2015. 367-373.

[8] Tim Manajemen Pendidikan UM. (2003). Manajemen Pendidikan. Malang: UM Press.

[9] Suprastowo, Philip. (2013). Kajian tentang Tingkat Ketidakhadiran Guru SD dan Dampaknya terhadap Siswa. Jurnal Pendidikan dan Kebudayaan. 19(1): 31-49.

[10] Lin, Ruilin dkk. (2010). The Relationship between Teacher Quality and Teaching Effectiveness Perceived by Students from Industrial Vocational High Schools. Asian Journal of Art and Science. 1 (2): 167-187.

[11] Narwoto. (2013). Faktor-faktor yang Berpengaruh terhadap Prestasi Belajar Teori Kejuruan Siswa SMK. Jurnal Pendidikan Vokasi. 3 (2): 222-233.

[12] Sanjaya, Wina . (2011). Strategi Pembelajaran, Jakarta: Kencana.

[13] Toht, Peter. (2012). Learning Strategies and Style in Vocational Education. Acta Polytechnica Hungarica. 9 (3): 195-216.

[14] Magno, Cario \& Sembrano, Josefina. (2007). The Role of Teacher Efficacy and Characteristics on Teaching Effectiveness, Performance, and Use of Learner- Centered Practices. The Asia Pacific Education Researcher. 16 (1): 73-90.

[15] Leluhur, Waris. (2012). Pengaruh Persepsi Pembelajaran Model Artikulasi dengan Media LCD Proyektor dan Tingkat Motivasi Belajar terhadap Prestasi Belajar Siswa pada Mata Pelajaran IPS Kelas VIII SMPN 1 Licin Semester 2 2011/2012. Jurnal Ilmiah Progresif. 9(25): 79-111.

[16] Irmayanti, L.P Susy dkk. (2013). Kontribusi Persepsi Siswa tentang Kemampuan Guru Mengelola Pembelajaran, Kemampuan Verbal, dan Ekspektasi Karir Terhadap Prestasi Belajar Bahasa Inggris Siswa Kelas XI IPA pada SMAN di Kecamatan Tabanan. Jurnal Program Pascasarjana Universitas Pendidikan Ganesha Prodi Administrasi Pendidikan. 4(1): 1-13.

[17] Martens dkk. (2007). New Learning Design in Distance Education: The Impact on Student Perception and Motivation. Journal Distance Education. 28(1): 81-93.

[18] Vamela dkk. (2012). Persepsi Siswa Tentang Proses Pembelajaran oleh Guru Non PKN di SMA Bina Mulya Kedaton Bandar Lampung. Jurnal Penelitian Pendidikan. 1(1): 1-15.

[19] Sakti, Ivan Nurizal. (2013). Laporan Pengalaman Lapangan 2. Laporan tidak diterbitkan. Semarang: UNES

[20] Hasruddin. (2008). Memimpin Proses Pembelajaran Berorientasi pada Pencapaian Kompetensi. Jurnal Kajian Manajemen Pendidikan. 18(11): 47-55

[21] SumarnO, Wustqa \& Dhariva, Urwatul. (2014). Pengembangan Perangkat Pembelajaran pada Materi Pokok Kalkulus SMA Kelas XI Semester 2. Jurnal Riset Pendidikan Matematika. 1(2): 257-267.

[22] Partin, R. (2009). The Classroom Teacher's Survival Guide (3th ed). San Fransisco: John Wiley\&Sons. 
[23] Harjanto. (2003). Perencanaan Pengajaran. Jakarta: PT Rineka Cipta.

[24] Masdiana et al. (2014). Penerapan Pembelajaran Tematik untuk Meningkatkan Hasil Belajar IPA Materi pada Lingkungan Siswa Kelas I SDN 018 Letawa Kecamatan Sarjo Kabupaten Mamuju Utara. Jurnal Kreatif Tadulako. 3(2): 190-204.

[25] Taufina. (2009). Authentic Assessment dalam Pembelajaran Bahasa Indonesia di Kelas Rendah SD. Jurnal Ilmiah Ilmu Pendidikan. 9(1) 113-120.

[26] Sutarjo. (2014). Supervisi Pengawas \& Kepala Sekolah dalam Peningkatan Mutu Pembelajaran. Jurnal Pendidikan Unsika. 2(1): 105-117.
[27] Nurmalasari, Riana. (2014). Hubungan Persepsi Siswa tentang Pelaksanaan Program Sarjana mengajar dan Pelaksanaan Pembelajaran Mata Pelajaran Produktif pada Program Keahlian Teknik Sepeda Motor di SMKN 1 Pujon. Skripsi tidak diterbitkan. Malang: FT UM.

[28] Suhardan, Dadang. (2007). Efektivitas Pengawasan Profesional dalam Meningkatkan Mutu Pembelajaran pada Era Otonomi Daerah. Jurnal Educationist. 1(1): 57-65. 